\title{
ReSEARChArticle
}

\section{Association of characters and path of action in table pea (Pisum sativum L.)}

\author{
Pallavi Pathak and S.S. Gahalain
}

\section{SUMMARY}

From the data generated from ten varieties/strains namely, AP-2, AP-4, AP-5, AP-1, KS-185, KS-218, KS-601, KS-701, KS801 and AP-3 and their all possible combinations excluding reciprocals in table pea which were evaluated during 2015-16. The correlation co-efficient analysis revealed that green pod yield per plant showed positive and significant correlations with pod length (0.542), pod width (0.778), number of seeds per pod (0.615), number of pods per plant $(0.404)$, seed shell ratio (0.331) and protein content $(0.404)$. The positive and high direct effect of number of pods per plant $(0.398)$ followed by pod length (0.252), seed shell ratio (0.251) and plant height (0.138) indicated their importance for selection base on it. Seeds per pod and protein content had positive but low direct effect on green pod yield. The major indirect positive effect of seeds per pod via pod length, pod width via number of first fruiting node, number of pods per plant via pod width and no. of seeds per pod, pod width via days to $50 \%$ flowering and number of fertile branches per plant via number of first fruiting node had positive and high indirect effects which indicated that effective selection can made indirectly based on these characters.

Key Words : Table pea, Pisum sativum, Selection parameters, Correlation, Path analysis, Pod yield

How to cite this article: Pathak, Pallavi and Gahalain, S.S. (2018). Association of characters and path of action in table pea (Pisum sativum L.). Internat. J. Plant Sci., 13 (1): 131-134, DOI: 10.15740/HAS/IJPS/13.1/131-134.

Article chronicle : Received : 16.10 .2017 ; Revised : 01.12.2017; Accepted : 15.12.2017

\footnotetext{
$\longrightarrow$ MEMBERS OF THE RESEARCH FORUM

Author to be contacted :

Pallavi Pathak, S.S.J. Campus, Kumaun University, Almora

(Uttarakhand) India

Email : pathakfast@gmail.com

Address of the Co-authors:

S.S. Gahalain, S.S.J. Campus, Kumaun University, Almora (Uttarakhand) India
} 